Communication

\title{
Synthesis of Novel bis-1,5-Disubstituted-1H-Tetrazoles by an Efficient Catalyst-Free Ugi-Azide Repetitive Process
}

\author{
Luís E. Cárdenas-Galindo ${ }^{1, \dagger}$, Alejandro Islas-Jácome ${ }^{2, \dagger}$, Karla M. Colmenero-Martínez ${ }^{2, \dagger}$, \\ Antonio Martínez-Richa ${ }^{2, \dagger}$ and Rocío Gámez-Montaño ${ }^{2, *}$
}

1 Departamento Química Área Ambiental, Universidad Tecnológica de Salamanca, Av. Universidad Tecnológica No. 200, Col. Ciudad Bajío, Salamanca C.P. 36750, Gto., Mexico; E-Mail: 1cardenas@utsalamanca.edu.mx

2 Departamento de Química, División de Ciencias Naturales y Exactas, Universidad de Guanajuato, Noria Alta S/N, Col. Noria Alta, Guanajuato C.P. 36050, Gto., Mexico;

E-Mails: blackheim66@gmail.com (A.I.-J.); karlasol08@hotmail.com (K.M.C.-M.); richa@ugto.mx (A.M.-R.)

$\dagger$ These authors contributed equally to this work.

* Author to whom correspondence should be addressed; E-Mail: rociogm@ugto.mx; Tel.: +52-473-732-0006 (ext. 8191); Fax: +52-473-732-0006 (ext. 8168).

Academic Editor: Derek J. McPhee

Received: 26 November 2014 / Accepted: 25 December 2014 / Published: 16 January 2015

\begin{abstract}
A series of five novel bis-1,5-disubstituted-1H-tetrazoles (bis-1,5-DS-1H-T) were quickly prepared by a catalyst-free Ugi-azide repetitive process from easily accessible starting materials in excellent yields, either at room temperature $(88 \%-95 \%)$ or using mild MW-heating conditions $(80 \%-91 \%)$. These molecules may have a wide range of applications, such as chelating agents, organocatalysts and luminescent materials, and mainly as bioactive compounds.
\end{abstract}

Keywords: bis-1,5-disubstituted-1H-tetrazoles; Ugi-azide repetitive reaction; MW-assisted synthesis; catalyst-free; chelating agents 


\section{Introduction}

1,5-Disubstituted-1H-tetrazoles (1,5-DS- $1 H$-T) are a special kind of non-naturally occurring heterocycles having a wide range of applications, mainly in medicinal chemistry, since they have proven to be suitable bioisosteres of the cis-amide bonds of peptides, because of the capability to adopt their conformations [1]. For example, the 1,5-DS-1H-T 1 showed antifungal activity against Candida albicans, Cryptococcus neoformans and Aspergillus niger comparable to the most potent commercially available antimycotics, such as fluconazole and itraconazole [2]. In the same context, the in-clinical phase drug, BMS-317180 (2), is a potent orally agonist of the human growth hormone, secretagogue [3] (Figure 1). It is noteworthy that the most used methods toward the synthesis of the 1,5-DS- $1 H$-T are both click [ $3+2]$ dipolar cycloadditions of organic azides with cyanides [4-7] and the Ugi-azide reaction between amines, aldehydes, isocyanides and hydrazoic acid [8].
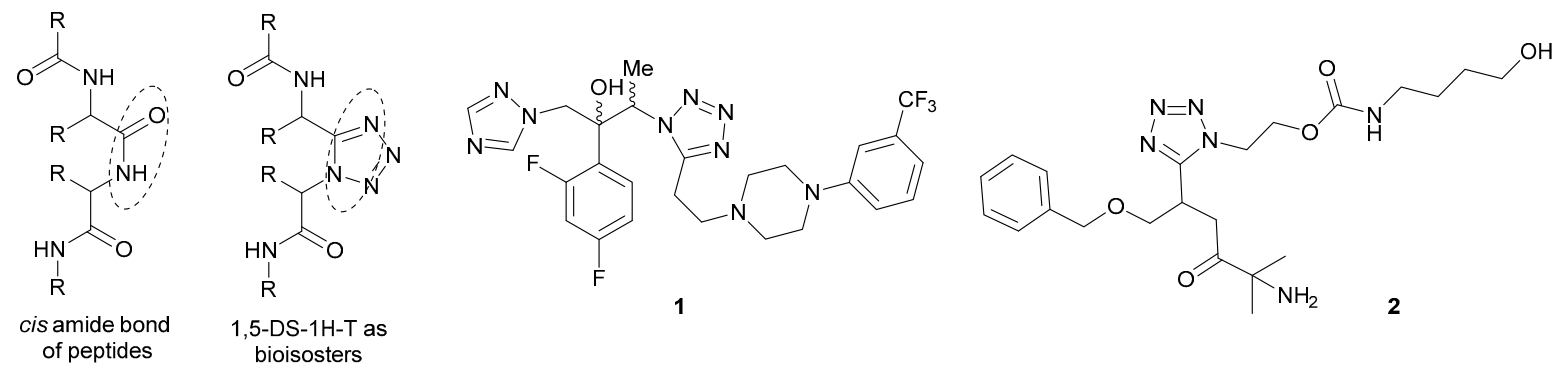

Figure 1. Some representative 1,5-disubstituted- $1 H$-tetrazoles $(1,5-\mathrm{DS}-1 H$-T $)$ having biological activity.

The synthesis, biological activity and other applications of molecules having two or more tetrazole rings in their structures have been reported little in the literature. Particularly, the bis-1,5-DS-1H-T attracted our attention, since they have shown interesting properties. Mazzanti and co-workers reported the use of the terpyridine linear-based bis-tetrazole $\mathbf{3}$ as a polydentate ligand of lanthanide cations, such as $\mathrm{Eu}^{\mathrm{III}}, \mathrm{Tb}^{\mathrm{III}}$ and $\mathrm{Nd}^{\mathrm{III}}$, allowing the synthesis of various potent luminescent materials [9]. The bis-sulfide-tetrazoles $\mathbf{4}$, which were biologically tested by Waisser and co-workers, showed a strong antiulcer, as well as antimycobacterial activity [10]. With the intention of preparing aminomethyltetrazole $9(85 \%)$ as an inhibitor of the $\gamma$-aminobutyric acid transporters, mGAT1-mGAT4, Wanner and co-workers synthesized bis-1,5-DS-1H-T 10 (9\%) as a by-product of an Ugi-azide reaction from amine 5, paraformaldehyde (6), isocyanide 7 and azidotrimethylsilane (8) [11] (Figure 2).

Thus, based on our ongoing efforts in the development of short and versatile methodologies toward the synthesis of tetrazole-containing hybrid compounds having frameworks of interest in medicinal chemistry, such as terazol-chromones [12], tetrazol-tetrahydro- $\beta$ - $1 H$-carbolines [13] and tetrazol-azepinoindolones [14], we herein report the synthesis of a series of five novel bis-1,5-DS-1H-T 15a-e using a catalyst-free Ugi-azide repetitive process. 

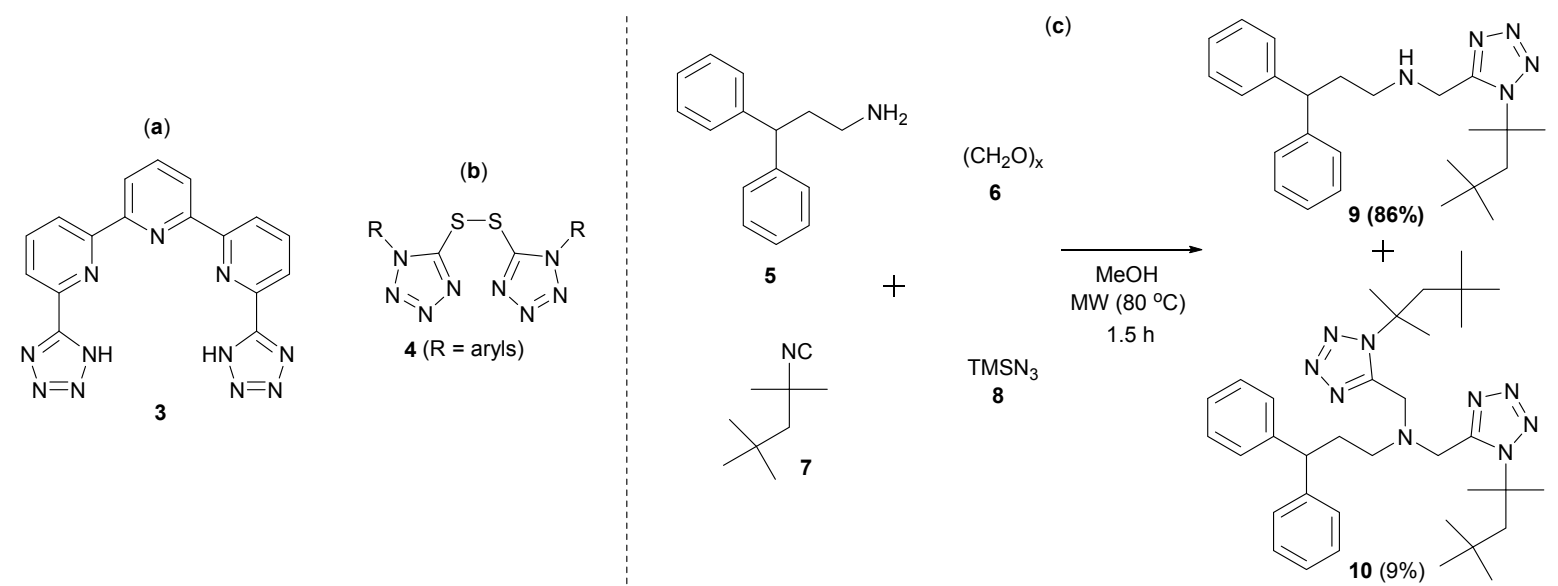

Figure 2. (a) Lanthanide cations ligand 3; (b) bioactive bis-1,5-DS-1H-T 4; (c) synthesis of the bis-1,5-DS-1H-T $\mathbf{1 0}$ as a by-product of a Ugi-azide reaction.

\section{Results and Discussion}

After optimizing the reaction conditions, the series of novel bis-1,5-DS-1H-T 15a-e were prepared by a sequential combination of one equivalent of amines 11, with two equivalents of aldehydes $\mathbf{1 2}$, isocyanides 13 and the azidotrimethylsilane $14 \mathrm{in} \mathrm{MeOH}(1.0 \mathrm{M})$ at room temperature under catalyst-free conditions in seven hours of reaction (Scheme 1). It is noteworthy that excellent yields were obtained (88\%-95\%). Compound 4a was synthesized with the best yield (95\%) when tert-butylamine (11a), paraformaldehyde (12a), 2,6-dimethylphenyl isocyanide (13a) and azidotrimethylsilane (14) were reacted together. This highest yield was observed possibly due to the high nucleophilicity of the tert-butylamine compared with the others amines used to complete the series. Then, with the intention of studying the effects coming from the amine moiety, the bis-1,5-DS-1H-T $\mathbf{1 5 b} \mathbf{b}-\mathbf{c}$ were prepared also in excellent yields (94\% and $92 \%$, respectively) by using amines with different stereoelectronic natures. Then, making a comparison between the yields of products $\mathbf{1 5 a}-\mathbf{c}$ (2,6-dimethylphenylisocyanide derivatives) and 15d-e (cyclohexyl isocyanide derivatives), it can be seen that the last ones were obtained in slightly lower yields, possibly due to the difference in the electronic nature coming just from the isocyanide substituent, which can affect the reaction course. One last interesting replacement was done when acetaldehyde was used instead of paraformaldehyde to prepare Compound 15e. As can be seen, the observed yield for this latter $(88 \%)$ is not much different with respect to the others despite the volatility of the acetaldehyde. Finally, with the intention of decreasing the reaction times, we used mild MW heating conditions, and slightly lower yields were observed with respect to those obtained at room temperature, but in only 15 minutes of reaction. It is noteworthy that the relationship of yields at room temperature and MW was kept. Compound 15a was obtained with the highest yield (91\%) and 15e with the lowest yield (80\%) (Scheme 1). 


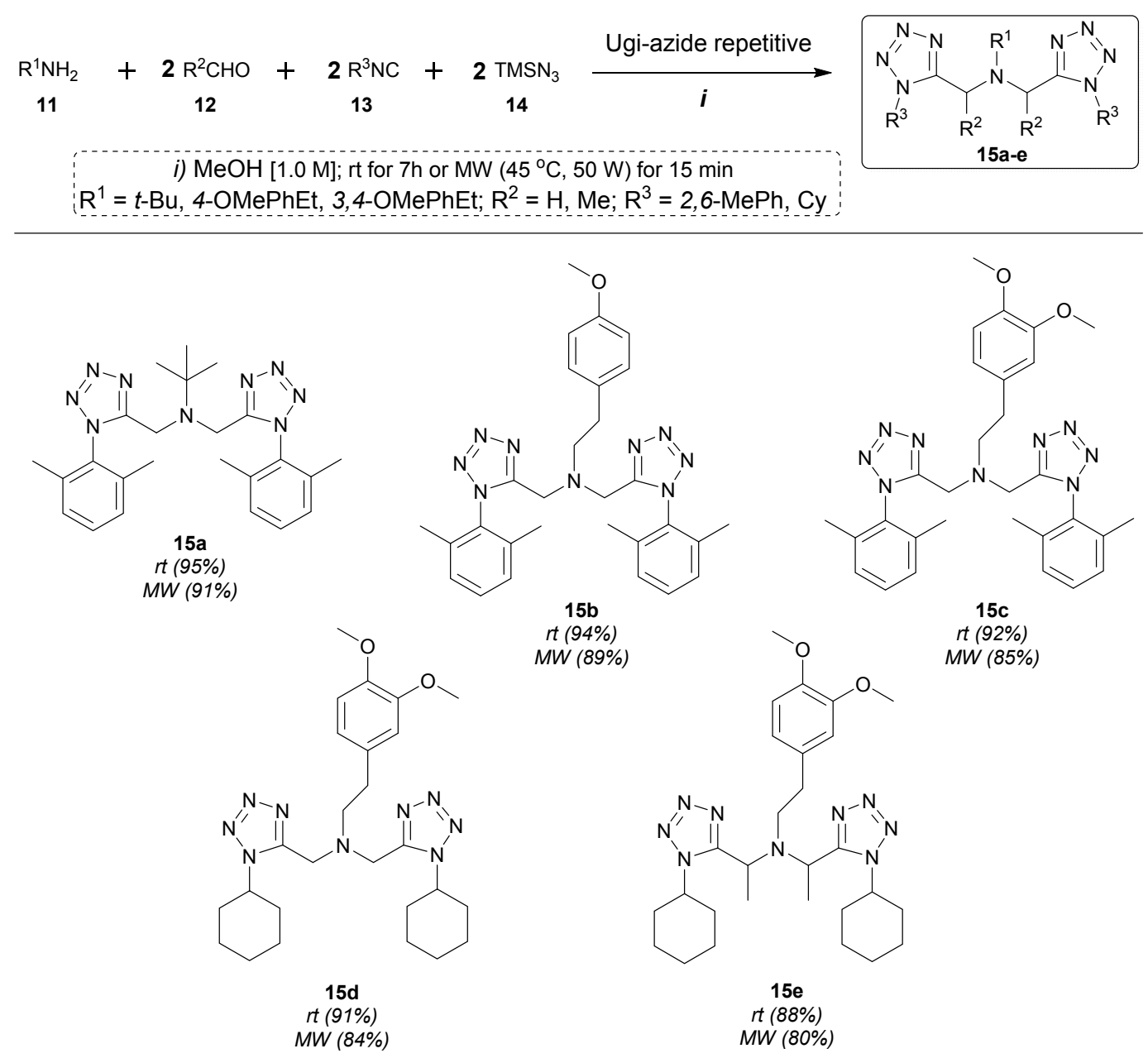

Scheme 1. Synthesis of bis-1,5-DS-1H-T 15a-e.

\section{Experimental Section}

${ }^{1} \mathrm{H}$ - and ${ }^{13} \mathrm{C}-\mathrm{NMR}$ spectra were acquired on Bruker Advance II spectrometers (200 or $300 \mathrm{MHz}$ ). The solvent was $\mathrm{CDCl}_{3}$. Chemical shifts are reported in parts per million $(\delta / \mathrm{ppm})$. The internal reference for ${ }^{1} \mathrm{H}-\mathrm{NMR}$ spectra is with respect to tetramethylsilane (TMS) at $0.0 \mathrm{ppm}$. The internal reference for ${ }^{13} \mathrm{C}-\mathrm{NMR}$ spectra is with respect to $\mathrm{CDCl}_{3}$ at $77.0 \mathrm{ppm}$. Coupling constants are reported in $\mathrm{Hertz}(\mathrm{J} / \mathrm{Hz})$. Multiplicities of the signals are reported using the standard abbreviations: singlet (s), doublet (d), triplet $(\mathrm{t})$, quartet (q) and multiplet (m). IR spectra were recorded on a Perkin Elmer 100 FTIR spectrometer using neat compounds, and the wavelengths are reported in reciprocal centimeters $\left(\mathrm{v} / \mathrm{cm}^{-1}\right)$. HRMS spectra were acquired on a JEOL JEM-AX505HA spectrometer, and the samples were ionized by FAB + and recorded via the TOF method. Microwave-assisted reactions were performed in closed vessel mode using a monomodal CEM Discover unit. The reaction progress was monitored by TLC, and the spots were visualized under UV light at 254 or $365 \mathrm{~nm}$. Flash column chromatography was performed using silica gel (230-400 mesh) and a mixture of hexanes with AcOEt (4:1 v/v) as the mobile phase. Melting points were determined on a Fisher-Johns apparatus and were uncorrected. All commercially available starting materials were used without further purification. The solvents were distilled and dried according to standard procedures. The NMR spectra of Compounds 15a-e are shown in the Supplementary Material. 


\section{General Procedures for the Synthesis of bis-1,5-Disubstituted-1H-tetrazoless 15a-e}

General Procedure 1 (GP-1) (room temperature conditions): In a round-bottomed flask equipped with a magnetic stirrer bar, to a $1.0 \mathrm{M}$ solution of amine 11 (1.0 equiv) in anhydrous $\mathrm{MeOH}$ under nitrogen atmosphere, aldehyde 12 (2.0 equiv), isocyanide 13 (2.0 equiv) and azidotrimethylsilane (14) (2.0 equiv) were sequentially added. The resulting mixture was stirred at room temperature for $7 \mathrm{~h}$. Then, the solvent was removed until dryness. The crude extract was diluted with $\mathrm{CH}_{2} \mathrm{Cl}_{2}(20 \mathrm{~mL})$ and washed with an excess of brine. The aqueous layer was extracted with $\mathrm{CH}_{2} \mathrm{Cl}_{2}(2 \times 10 \mathrm{~mL})$. The combined organic layer was dried over anhydrous $\mathrm{Na}_{2} \mathrm{SO}_{4}$, evaporated until dryness and purified by silica gel column chromatography using a mixture of hexanes with ethyl acetate $(4: 1 \mathrm{v} / \mathrm{v})$ as the mobile phase to afford the corresponding bis-1,5-disubstituted-1H-tetrazoles 15a-e.

General Procedure 2 (GP-2) (microwave heating conditions): In a MW sealed tube equipped with a magnetic stirring bar, to a $1.0 \mathrm{M}$ solution of amine 11 (1.0 equiv) in anhydrous $\mathrm{MeOH}$, aldehyde 12 (2.0 equiv), isocyanide 13 (2.0 equiv) and azidotrimethylsilane (14) (2.0 equiv) were sequentially added. The resulting mixture was MW-heated 3 times for 5 minutes at $45{ }^{\circ} \mathrm{C}(50 \mathrm{~W})$. Then, the solvent was removed until dryness. The crude extract was diluted with $\mathrm{CH}_{2} \mathrm{Cl}_{2}(20 \mathrm{~mL})$ and washed with an excess of brine. The aqueous layer was extracted with $\mathrm{CH}_{2} \mathrm{Cl}_{2}(2 \times 10 \mathrm{~mL})$. The combined organic layer was dried over anhydrous $\mathrm{Na}_{2} \mathrm{SO}_{4}$, evaporated until dryness and purified by silica gel column chromatography using a mixture of hexanes with ethyl acetate $(4: 1 \mathrm{v} / \mathrm{v})$ as the mobile phase to afford the corresponding bis-1,5-disubstituted-1H-tetrazoles 15a-e.

$N, N$-bis((1-(2,6-Dimethylphenyl)-1H-tetrazol-5-yl)methyl)-2-methylpropan-2-amine (15a). $t$-Butylamine (150 mg, $2.05 \mathrm{mmol}$ ), paraformaldehyde (123 mg, $4.10 \mathrm{mmol}$ ), 2,6-dimethylphenyl isocyanide (538 $\mathrm{mg}$, $4.10 \mathrm{mmol}$ ) and azidotrimethylsilane $(473 \mathrm{mg}, 4.10 \mathrm{mmol})$ were reacted together in anhydrous $\mathrm{MeOH}$ (2.1 mL) to afford Compound 15a (866 mg, 95\%, GP-1; $829 \mathrm{mg}, 91 \%$, GP-2) as a white powder; $\mathrm{mp}=132-134{ }^{\circ} \mathrm{C} ; \mathrm{R}_{f}=0.48\left(\mathrm{Hex} /\right.$ AcOEt 4:1 v/v); FTIR (Attenuated Total Reflection, ATR) $v_{\max } / \mathrm{cm}^{-1}$ 776, 784, 845, 929, 1035, 1112, 1086, 1196, 1369, 1483, 1719, 2963; ${ }^{1} \mathrm{H}-\mathrm{NMR}$ (300 MHz; CDCl ; $25^{\circ} \mathrm{C}$; TMS): $\delta 0.87$ (s, 9H), $1.98(\mathrm{~s}, 12 \mathrm{H}), 4.06(\mathrm{~s}, 4 \mathrm{H}), 7.24(\mathrm{~d}, 4 \mathrm{H}, J=7.4 \mathrm{~Hz}), 7.39$ (dd, 2H, $J=8.2$, $7.0 \mathrm{~Hz}) ;{ }^{13} \mathrm{C}-\mathrm{NMR}\left(75 \mathrm{MHz}, \mathrm{CDCl}_{3} ; 25{ }^{\circ} \mathrm{C}\right.$; TMS): $\delta$ 17.7, 27.6, 41.1, 56.0, 129.1, 131.1, 131.9, 136.0, 154.8; HRMS [M-H] $]^{+} \mathrm{m} / z$ calcd. for $\mathrm{C}_{24} \mathrm{H}_{32} \mathrm{~N}_{9}{ }^{+} 446.2781$, found 446.2775 .

N,N-bis((1-(2,6-Dimethylphenyl)-1H-tetrazol-5-yl)methyl)-2-(4-methoxyphenyl)ethan-1-amine (15b). 4-Methoxyphenethylamine (300 mg, $1.98 \mathrm{mmol})$, paraformaldehyde (119 mg, $3.97 \mathrm{mmol})$, 2,6-dimethylphenyl isocyanide (521 mg, $3.97 \mathrm{mmol}$ ) and azidotrimethylsilane (457 $\mathrm{mg}, 3.97 \mathrm{mmol}$ ) were reacted together in $\mathrm{MeOH}(2.0 \mathrm{~mL})$ to afford Compound 15b (973 mg, 94\%, GP-1; $921 \mathrm{mg}, 89 \%$, GP-2) as a white powder; $\mathrm{mp}=154-156^{\circ} \mathrm{C} ; \mathrm{R}_{f}=0.23(\mathrm{Hex} /$ AcOEt $4: 1 \mathrm{v} / \mathrm{v})$; FTIR (ATR) $v_{\max } / \mathrm{cm}^{-1} 779$, 1031, 1104, 1123, 1243, 1452, 1481, 1509, 1608, 2150, 2834, 2928; ${ }^{1} \mathrm{H}-\mathrm{NMR}\left(200 \mathrm{MHz} ; \mathrm{CDCl}_{3} ; 25^{\circ} \mathrm{C}\right.$; TMS): $\delta 1.87(\mathrm{~s}, 12 \mathrm{H}), 2.32(\mathrm{dd}, 2 \mathrm{H}, J=9.2,6.6 \mathrm{~Hz}), 2.90(\mathrm{dd}, 2 \mathrm{H}, J=9.3,6.6 \mathrm{~Hz}), 3.75(\mathrm{~s}, 3 \mathrm{H}), 3.92(\mathrm{~s}$, $4 \mathrm{H}), 6.74(\mathrm{~d}, 2 \mathrm{H}, J=8.6 \mathrm{~Hz}), 6.86(\mathrm{~d}, 2 \mathrm{H}, J=8.6 \mathrm{~Hz}), 7.21(\mathrm{~d}, 4 \mathrm{H}, J=7.6 \mathrm{~Hz}), 7.38(\mathrm{dd}, 2 \mathrm{H}$, $J=8.3,6.9 \mathrm{~Hz}) ;{ }^{13} \mathrm{C}-\mathrm{NMR}\left(50 \mathrm{MHz}, \mathrm{CDCl}_{3} ; 25{ }^{\circ} \mathrm{C}\right.$; TMS $): \delta 17.5,32.9,45.3,55.3,56.1,114.0,129.1$, 129.4, 130.7, 131.2, 131.7, 135.7, 152.9, 158.2; HRMS $[\mathrm{M}-\mathrm{H}]^{+} \mathrm{m} / z$ calcd. for $\mathrm{C}_{29} \mathrm{H}_{34} \mathrm{ON}_{9}{ }^{+} 524.2886$, found 524.2885 . 
2-(3,4-Dimethoxyphenyl)-N,N-bis((1-(2,6-dimethylphenyl)-1H-tetrazol-5-yl)methyl)ethan-1-amine

(15c).

3,4-Dimethoxyphenethylamine (500 $\mathrm{mg}, 2.76 \mathrm{mmol})$, paraformaldehyde (166 mg, $5.52 \mathrm{mmol}$ ), 2,6-dimethylphenyl isocyanide (724 mg, $5.52 \mathrm{mmol}$ ) and azidotrimethylsilane (636 $\mathrm{mg}, 5.52 \mathrm{mmol})$ were reacted together in $\mathrm{MeOH}(2.8 \mathrm{~mL})$ to afford Compound 15c (1405 mg, 92\%, GP-1; $1298 \mathrm{mg}$, $85 \%$, GP-2) as a yellow powder; $\mathrm{mp}=48-50{ }^{\circ} \mathrm{C} ; \mathrm{R}_{f}=0.49(\mathrm{Hex}-\mathrm{AcOEt} 4: 1 \mathrm{v} / \mathrm{v})$; FTIR (ATR) $v_{\max } / \mathrm{cm}^{-1}$ 764, 1027, 1103, 1140, 1235, 1235, 1260, 1417, 1464, 1514, 1590, 2835, 2856, 2929; ${ }^{1} \mathrm{H}-\mathrm{NMR}$ (300 MHz; $\mathrm{CDCl}_{3} ; 25^{\circ} \mathrm{C}$; TMS): $\delta 1.86(\mathrm{~s}, 12 \mathrm{H}), 2.36(\mathrm{~m}, 2 \mathrm{H}), 2.94(\mathrm{~m}, 2 \mathrm{H}), 3.82(\mathrm{~s}, 6 \mathrm{H}), 3.92(\mathrm{~s}, 4 \mathrm{H}), 6.46-6.52$ $(\mathrm{m}, 2 \mathrm{H}), 6.70(\mathrm{~d}, 1 \mathrm{H}, J=8.1 \mathrm{~Hz}), 7.21(\mathrm{~d}, 4 \mathrm{H}, J=7.6 \mathrm{~Hz}), 7.38(\mathrm{~m}, 2 \mathrm{H}) ;{ }^{13} \mathrm{C}-\mathrm{NMR}\left(75 \mathrm{MHz}, \mathrm{CDCl}_{3}\right.$; $25^{\circ} \mathrm{C}$; TMS): $\delta 17.4,33.3,45.4,55.8,56.0,111.5,111.9,120.4,128.9,129.0,131.1,131.4,131.6,135.7$, 147.7, 149.1, 152.9; HRMS [M-H] ${ }^{+} m / z$ calcd. for $\mathrm{C}_{30} \mathrm{H}_{35} \mathrm{O}_{2} \mathrm{~N}_{9}{ }^{+}$554.2992, found 554.2981.

N,N-bis((1-Cyclohexyl-1H-tetrazol-5-yl)methyl)-2-(3,4-dimethoxyphenyl)ethan-1-amine

(15d). 3,4-Dimethoxyphenethylamine (300 $\mathrm{mg}, 1.66 \mathrm{mmol}$ ), paraformaldehyde (99 mg, $3.31 \mathrm{mmol}$ ), cyclohexyl isocyanide $(361 \mathrm{mg}, 3.97 \mathrm{mmol})$ and azidotrimethylsilane $(381 \mathrm{mg}, 3.31 \mathrm{mmol})$ were reacted together in $\mathrm{MeOH}(1.7 \mathrm{~mL})$ to afford Compound 15d (768 mg, 91\%, GP-1; $708 \mathrm{mg}, 84 \%$, GP-2) as a white powder; $\mathrm{mp}=126-12{ }^{\circ} \mathrm{C} ; \mathrm{R}_{f}=0.42(\mathrm{Hex} / \mathrm{AcOEt} 4: 1 \mathrm{v} / \mathrm{v})$; FTIR (ATR) $v_{\max } / \mathrm{cm}^{-1} 782,1033$, 1119, 1108, 1227, 1463, 1492, 1521, 1615, 2129, 2851, 2935; ${ }^{1} \mathrm{H}-\mathrm{NMR}\left(200 \mathrm{MHz} ; \mathrm{CDCl}_{3} ; 25{ }^{\circ} \mathrm{C}\right.$; TMS): $\delta 1.19-1.34(\mathrm{~m}, 7 \mathrm{H}), 1.82-1.90(\mathrm{~m}, 13 \mathrm{H}), 2.73(\mathrm{t}, 2 \mathrm{H}, J=7.4 \mathrm{~Hz}), 2.93(\mathrm{t}, 2 \mathrm{H}, J=7.4 \mathrm{~Hz}), 3.74$ (s, 3H), 3.76 (s, 3H), 3.98 (s, 4H), 4.07-4.15 (m, 2H), 6.58 (d, 2H, J=7.7 Hz), 6.75 (d, 1H, J=7.8 Hz);

${ }^{13} \mathrm{C}-\mathrm{NMR}\left(50 \mathrm{MHz}, \mathrm{CDCl}_{3} ; 25{ }^{\circ} \mathrm{C}\right.$; TMS): $\delta$ 24.9, 25.2, 32.9, 46.0, 56.1, 57.9, 111.4, 111.9, 120.5, 131.4, 147.8, 149.2, 150.9; HRMS [M-H] ${ }^{+} \mathrm{m} / z$ calcd. for $\mathrm{C}_{26} \mathrm{H}_{39} \mathrm{~N}_{9} \mathrm{O}_{2} 510.3299$, found 510.3298 .

1-(1-Cyclohexyl-1H-tetrazol-5-yl)-N-(1-(1-cyclohexyl-1H-tetrazol-5-yl)ethyl)-N-(3,4-dimethoxyphenet hyl)ethan-1-amine (15e). 3,4-Dimethoxyphenethylamine (300 mg, $1.66 \mathrm{mmol})$, acetaldehyde (146 mg, $3.31 \mathrm{mmol}$ ), cyclohexyl isocyanide (361 mg, $3.31 \mathrm{mmol}$ ) and azidotrimethylsilane (381 mg, $3.31 \mathrm{mmol})$ were reacted together in $\mathrm{MeOH}(1.7 \mathrm{~mL})$ to afford Compound 15e (783 mg, 88\%, GP-1; 711, 80\%, GP-2) as a white powder; $\mathrm{mp}=115-117^{\circ} \mathrm{C} ; \mathrm{R}_{f}=0.46(\mathrm{Hex} /$ AcOEt $4: 1 \mathrm{v} / \mathrm{v})$; FTIR (ATR) $\mathrm{v}_{\max } / \mathrm{cm}^{-1} 749$, 759, 808, 1027, 1048, 1233, 1263, 1456, 1,586, 1512, 1672, 2858, 2935, 3339; ${ }^{1} \mathrm{H}-\mathrm{NMR}(300 \mathrm{MHz}$; $\mathrm{CDCl}_{3} ; 25^{\circ} \mathrm{C}$; TMS): $\delta 1.28(\mathrm{~d}, 6 \mathrm{H}, J=6.9 \mathrm{~Hz}), 1.44-1.60(\mathrm{~m}, 4 \mathrm{H}), 1.78-2.05(\mathrm{~m}, 12 \mathrm{H}), 2.12-2.19(\mathrm{~m}$, $4 \mathrm{H}), 2.74(\mathrm{~m}, 2 \mathrm{H}), 3.33(\mathrm{~m}, 2 \mathrm{H}), 3.87(\mathrm{~s}, 3 \mathrm{H}), 3.89(\mathrm{~s}, 3 \mathrm{H}), 4.23(\mathrm{q}, 2 \mathrm{H}, J=6.9 \mathrm{~Hz}), 4.39-4.49(\mathrm{~m}, 2 \mathrm{H})$, $6.66(\mathrm{~d}, 1 \mathrm{H}, J=1.9 \mathrm{~Hz}), 6.72(\mathrm{dd}, 1 \mathrm{H}, J=8.1,1.9 \mathrm{~Hz}), 6.81(\mathrm{~d}, 1 \mathrm{H}, J=8.1 \mathrm{~Hz}) ;{ }^{13} \mathrm{C}-\mathrm{NMR}(75 \mathrm{MHz}$, $\mathrm{CDCl}_{3} ; 25^{\circ} \mathrm{C}$; TMS): $\delta 17.2,25.0,25.5,25.5,32.7,34.0,36.9,47.9,48.4,56.2,56.2,57.8,111.7,112.1$, 120.7, 131.6, 148.0, 149.3, 155.2; HRMS [M-H] ${ }^{+} \mathrm{m} / z$ calcd. for $\mathrm{C}_{28} \mathrm{H}_{44} \mathrm{O}_{2} \mathrm{~N}_{9}{ }^{+}$538.3618, found 538.3629.

\section{Conclusions}

A series of five novel bis-1,5-disubstituted-1H-tetrazoles (bis-1,5-DS-1H-T) were quickly prepared by a catalyst-free Ugi-azide repetitive process from easily accessible starting materials in excellent yields, either at room temperature $(88 \%-95 \%)$ or using mild MW-heating conditions $(80 \%-91 \%)$. The yields are slightly dependent on stereo-electronic factors. The methodology herein described could be considered as a pioneering work in the one pot synthesis of bis-1,5-DS-1H-T, which, in fact, could present a wide range of applications, such as luminescent materials, anionic chelating agents or bioactive compounds. 


\section{Supplementary Materials}

Supplementary materials can be accessed at: http://www.mdpi.com/1420-3049/20/01/1519/s1.

\section{Acknowledgments}

R.G.-M. thanks CONACYT (Project: CB-2011-166747-Q) and Dirección de Apoyo a la Investigación y al Posgrado-Universidad de Guanajuato (DAIP-UG) for the financial support and also Gabriel Cuevas from Instituto de Química-Universidad Nacional Autónoma de México (IQ-UNAM) for technical support with respect to HRMS. The post-doctoral scholarship awarded to A.I.-J. (\#promep-103.5/13/5669) by Secretaría de Educación Pública-Programa de Mejoramiento del Profesorado (SEP-PROMEP) is gratefully acknowledged. All authors kindly acknowledge Laboratorio Nacional de Caracterización de Propiedades Fisicoquímicas y Estructura Molecular (CONACYT, Project: 123732).

\section{Author Contributions}

L.E.C.-G. synthesized the compounds 15a-e at room temperature while K.M.C.-M. did it under MW heating conditions. A.I.-J. contributed to writing and editing the manuscript. A.M.-R. was co-researcher of this work. R.G.-M. is the responsible researcher and to whom correspondence must be addressed. Authors contributed equally to this work.

\section{Conflicts of Interest}

The authors declare no conflict of interest.

\section{References}

1. Zabrocki, J.; Smith, G.D.; Dunbar, J.B., Jr.; Iijima, H.; Marshall, G.R. Conformational mimicry. 1. 1,5-Disubstituted tetrazole ring as surrogate for the cis amide bond. J. Am. Chem. Soc. 1988, 110, 5875-5880.

2. Upadhayaya, R.S.; Jain, S.; Sinha, N.; Kishore, N.; Chandra, R.; Arora, S.K. Synthesis of novel substituted tetrazoles having antifungal activity. Eur. J. Med. Chem. 2004, 39, 579-592.

3. Davulcu, A.H.; McLeod, D.D.; Li, J.; Katipally, K.; Littke, A.; Doubleday, W.; Xu, Z.; McConlogue, C.W.; Lai, C.J.; Gleeson, M.; et al. Process research and development for a tetrazole-based growth hormone secretagogue (GHS) pharmaceutical development candidate. J. Org. Chem. 2009, 74, 4068-4079.

4. Sarvary, A.; Maleki, A. A review of synthesis of 1,5-disubstituted tetrazole derivatives. Mol. Divers. 2014, doi:10.1007/s11030-014-9553-3.

5. Bräse, S.; Gil, C.; Knepper, K.; Zimmermann, V. Organic azides: An exploiting diversity of a unique class of compounds. Angew. Chem. Int. Ed. 2005, 44, 5188-5240.

6. Himo, F.; Demko, Z.P.; Noodleman, L.; Sharpless, K.B. Mechanism of tetrazole formation by addition of azide to nitriles. J. Am. Chem. Soc. 2002, 124, 12210-12216.

7. Scriven, E.F.V.; Turnbull, K. Azides: Their preparation and synthetic uses. Chem. Rev. 1988, 88, 297-368. 
8. El Kaim, L.; Grimaud, L. Beyond the Ugi reaction: Less conventional interactions between isocyanides and iminium species. Tetrahedron 2009, 65, 2153-2171.

9. Giraud, M.; Andreiadis, E.S.; Fisyuk, A.S.; Demadrille, R.; Pécaut, J.; Imbert, D.; Mazzanti, M. Efficient sensitization of lanthanide luminescence by tetrazole-based polydentate ligands. Inorg. Chem. 2008, 47, 3952-3954.

10. Waisser, K.; Adamec, J.; Kunes, J.; Kaustova, J. Antimycobacterial 1-aryl-5-benzylsulfanyl tetrazoles. Chem. Pap. 2004, 58, 214-219.

11. Schaffert, E.S.; Höfner, G.; Wanner, K.T. Aminomethyltetrazoles as potential inhibitors of the $\gamma$-aminobutyric acid transporters mGAT1-mGAT4: Synthesis and biological evaluation. Bioorg. Med. Chem. 2011, 19, 6492-6504.

12. Cano, P.A.; Islas-Jácome, A.; González-Marrero, J.; Yépez-Mulia, L.; Calzada, F.; Gámez-Montaño, R. Synthesis of 3-tetrazolylmethyl-4H-chromen-4-ones via Ugi-azide and biological evaluation against Entamoeba histolytica, Giardia lamblia and Trichomonas vaginalis. Bioorg. Med. Chem. 2014, 22, 1370-1376.

13. Cárdenas-Galindo, L.E.; Islas-Jácome, A.; Alvarez-Rodríguez, N.V.; El Kaim, L.; Gámez-Montaño, R. Synthesis of 2-tetrazolylmethyl-2,3,4,9-tetrahydro- $1 H$ - $\beta$-carbolines by a one pot Ugi-azide/Pictet-spengler process. Synthesis 2014, 46, 49-56.

14. Gordillo-Cruz, R.E.; Rentería-Gómez, A.; Islas-Jácome, A.; Cortes-García, C.J.; Díaz-Cervantes, E.; Robles, J.; Gámez-Montaño, R. Synthesis of 3-tetrazolylmethyl-azepino[4,5- $b$ ]indol-4-ones in two reaction steps: (Ugi-azide/ $N$-acylation/ $\mathrm{S}_{\mathrm{N}}$ 2)/free radical cyclization and docking studies to a 5-Ht6 model. Org. Biomol. Chem. 2013, 11, 6470-6476.

Sample Availability: Samples of the compounds 15a-e are available from the authors.

(C) 2015 by the authors; licensee MDPI, Basel, Switzerland. This article is an open access article distributed under the terms and conditions of the Creative Commons Attribution license (http://creativecommons.org/licenses/by/4.0/). 